\title{
COMPARISON OF NON-THERMAL PLASMA DECOMPOSITION CHARACTERISTICS OF ORGANO-HALIDE GASES UNDER OXIDIZING AND REDUCING ATMOSPHERE
}

\author{
A. YOKOI $^{1, *}$ \\ T. FUJITA ${ }^{1}$ \\ D. KUCHAR ${ }^{1}$ \\ M. KUBOTA ${ }^{1}$ \\ H. LIWEI ${ }^{2}$ \\ K. USHIROEBISU ${ }^{3}$ \\ H. MATSUDA ${ }^{1}$
}

${ }^{1}$ Energy Engineering and Science, Nagoya University
Furo-cho Chikusa-ku, Nagoya, Aichi, 464-8603, Japan
${ }^{2}$ College of Biological and Environmental Engineering
Zhejiang University of Technology
Hangzhou, Zhejiang Province, 310027, P.R. China
${ }^{3}$ Engineering Division, Sintokogio Ecotec Company
1, Nishinagane, Sakazaki, Koda-cho, Aichi
444-0104, Japan

*to whom all correspondence should be addressed: e-mail: a-yokoi@ees.nagoya-u.ac.jp

\begin{abstract}
Halide gases used in various industrial processes significantly contribute to the greenhouse effect owing to their high GWPs. In addition, the halide gases have high chemical stability and thus remain in the atmosphere for a long period. Therefore, effective treatment techniques of halide gases are required to achieve environmental protection. The present work is concerned with the destruction of halide gases such as $\mathrm{CF}_{4}, \mathrm{CHF}_{3}$ and $\mathrm{CHClF}_{2}$ in a wire-intube pulsed corona reactor. In details, the influence of coexisting gases of $\mathrm{H}_{2}$ and $\mathrm{O}_{2}$ on nonthermal plasma (NTP) decomposition of $\mathrm{CF}_{4}, \mathrm{CHF}_{3}$ and $\mathrm{CHClF}_{2}$ was investigated. As a result, decomposition ratios of $\mathrm{CF}_{4}$ and $\mathrm{CHClF}_{2}$ by NTP were found to be higher under $\mathrm{H}_{2}-\mathrm{N}_{2}$ atmosphere than under $\mathrm{N}_{2}$ atmosphere. By contrast, the decomposition ratio of $\mathrm{CHF}_{3}$ under $\mathrm{H}_{2}-\mathrm{N}_{2}$ atmosphere was lower than that under $\mathrm{N}_{2}$ atmosphere. In the case of $\mathrm{O}_{2}-\mathrm{N}_{2}$ atmosphere, lower decomposition ratios of $\mathrm{CF}_{4}, \mathrm{CHF}_{3}$ and $\mathrm{CHClF}_{2}$ were obtained under $\mathrm{O}_{2}$ $\mathrm{N}_{2}$ atmosphere than under $\mathrm{N}_{2}$ atmosphere. Additionally, $\mathrm{CHClF}_{2}$ decomposition by NTP in the presence of $\mathrm{O}_{2}$ yielded the reaction products such as $\mathrm{CCl}_{2} \mathrm{~F}_{2}, \mathrm{COCl}_{2}, \mathrm{COF}_{2}$ and $\mathrm{CO}_{2}$. Then, as the $\mathrm{O}_{2}$ concentration increased, the formation of undesirable product of $\mathrm{CCl}_{2} \mathrm{~F}_{2}$ decreased, while the generation of $\mathrm{CO}_{2}$ increased.
\end{abstract}

KEYWORDS: non-thermal plasma, halide gases, $\mathrm{H}_{2}$ concentration, $\mathrm{O}_{2}$ concentration.

\section{INTRODUCTION}

Greenhouse gases such as $\mathrm{CF}_{4}, \mathrm{CHF}_{3}$ and $\mathrm{CHClF}_{2}$ are widely used as organic solvents, refrigerants and dry etching agents in semiconductor industry, air conditioners and other industrial processes. However, these gases have high GWPs (Global Warming Potentials), toxicity, and may remain in the atmosphere for a long period, due to their chemical stability (Kataoka, 2001; Mizuno, 2001). Hence, the effective techniques to prevent the release of halide gases into the environment are required.

In the recent years, non-thermal plasma has been noted as one of the prospective techniques for the decomposition of halide gases (Oda et al., 1996; Sathiamoorthy et al., 1999). In nonthermal plasma, the decomposition process starts with dissociation and/or excitation of targeted halide molecules by direct impact of energetic electrons. Further, active radicals such as $\mathrm{N}, \mathrm{H}, \mathrm{O}$ can be formed by dissociation and ionization of background gases. Then, the initiation is followed by so called chain reactions leading to the formation of various 
byproducts. The chain reactions between the radicals and halide molecules propagate until stable products are formed.

In our previous study, the plasma decomposition of dichloromethane $\left(\mathrm{CH}_{2} \mathrm{Cl}_{2}\right)$ in a pulse corona reactor with and without $\mathrm{Ca}(\mathrm{OH})_{2}$ alkaline absorbent under $\mathrm{N}_{2}$ and $\mathrm{O}_{2}$ atmosphere was performed (Huang et al., 2001). During the plasma decomposition of $\mathrm{CH}_{2} \mathrm{Cl}_{2}$ using a plasma reactor without absorbent, $\mathrm{HCl}$ was detected as a byproduct under $\mathrm{N}_{2}$ atmosphere, while $\mathrm{CO}, \mathrm{CO}_{2}, \mathrm{COCl}_{2}$ and $\mathrm{NOx}$ were the main byproducts found in the presence of oxygen. By contrast, when the corona reactor was combined with $\mathrm{Ca}(\mathrm{OH})_{2}$ absorbent, $\mathrm{HCl}$ and $\mathrm{COCl}_{2}$ were not detected during plasma decomposition of halide gases under $\mathrm{O}_{2}$ atmosphere. In a subsequent study (Hari et al., 2002), the plasma decomposition of halide gases $\left(\mathrm{CCl}_{4}, \mathrm{SF}_{6}\right.$, $\mathrm{CHF}_{3}$ and $\mathrm{CHClF}_{2}$ ) in a plasma reactor with/without in-situ alkaline absorbent was investigated under $\mathrm{N}_{2}$ and $2 \% \mathrm{H}_{2}$ atmospheres. At first, without in-situ alkaline absorbent, it was found that the decomposition ratios of $\mathrm{SF}_{6}, \mathrm{CCl}_{4}$ and $\mathrm{CHClF}_{2}$ increased with the addition of $2 \% \mathrm{H}_{2}$ to $\mathrm{N}_{2}$ compared to those under $\mathrm{N}_{2}$ atmosphere alone. However, in the case of $\mathrm{CHF}_{3}$, the decomposition ratio was lower in $2 \% \mathrm{H}_{2}$ atmosphere than that under $\mathrm{N}_{2}$ atmosphere. Further, when non-thermal plasma was combined with in-situ $\mathrm{Ca}(\mathrm{OH})_{2}$ absorption under $\mathrm{N}_{2}$ and $2 \% \mathrm{H}_{2}$ atmospheres, the decomposition ratios of $\mathrm{SF}_{6}, \mathrm{CCl}_{4}$ and $\mathrm{CHClF}_{2}$ were higher than those without $\mathrm{Ca}(\mathrm{OH})_{2}$ absorption and products such as $\mathrm{HCl}, \mathrm{Cl}_{2}, \mathrm{HF}$ and $\mathrm{F}_{2}$ were found to be effectively removed. The results of these studies indicated that the decomposition of halides and absorption of halogen $(\mathrm{Cl}$ and $\mathrm{F}$ ) were promoted by the formation of hydrogen halides $(\mathrm{HCl}$ and $\mathrm{HF})$, and there was an optimum $\mathrm{H}_{2}$ concentration for the decomposition of halide gases to form hydrogen halides. Therefore, it was of great importance to understand the behavior of plasma decomposition of halides in the presence of $\mathrm{H}_{2}$ and $\mathrm{O}_{2}$.

Hence, in this study, non-thermal plasma decomposition of $\mathrm{CF}_{4}, \mathrm{CHF}_{3}$ and $\mathrm{CHClF}_{2}$ under $\mathrm{N}_{2}$, $\mathrm{H}_{2}-\mathrm{N}_{2}$ and $\mathrm{O}_{2}-\mathrm{N}_{2}$ atmospheres was thoroughly studied. It was considered that, in hydrogenenriched atmosphere, the halogen atoms are converted to stable hydrogen halides. On the other hand, under $\mathrm{O}_{2}-\mathrm{N}_{2}$ atmosphere, it was expected that carbon in the structure of halide gases is converted to $\mathrm{CO}_{2}$ having lower GWP than halide gases.

\section{EXPERIMENTAL}

In this study, a typical wire-tube combination corona reactor was used for the experiments and the schematic diagram of experimental apparatus is shown in Figure 1.

The reactor consisted of a Pyrex glass tube with an aluminum film attached to the outer wall as the grounding electrode and a coaxial stainless steel wire as the corona wire. Using an AC power source, input voltage (5.0-9.5 kV) was applied to the wire electrode and the experiments were carried out at an input power range of 0.04-0.15 kW and at a fixed frequency of $1.0 \mathrm{kHz}$. During the experiments, no temperature adjustment was performed and the experiments were conducted at an ambient temperature.

The prepared sample gases of $\mathrm{CF}_{4}, \mathrm{CHF}_{3}$ or $\mathrm{CHClF}_{2}$ were introduced to the reactor at a fixed flow rate of $200 \mathrm{ml} \mathrm{min}^{-1}$ (retention time: $68 \mathrm{~s}$ ) in all experiments. The concentrations of $\mathrm{CF}_{4}$, $\mathrm{CHF}_{3}$ and $\mathrm{CHClF}_{2}$ in all sample gas mixtures were adjusted to $25 \mathrm{ppm}$ or $100 \mathrm{ppm}$ under $\mathrm{N}_{2}$ gas, and the $\mathrm{H}_{2}$ or $\mathrm{O}_{2}$ concentration in the sample gases were adjusted to $0-20,000 \mathrm{ppm}$. The sample gases before and after the plasma treatment in the reactor were analyzed using an on-line FT-IR (SHIMADZU, FTIR-8700) with a gas cell of $10 \mathrm{~cm}$ path length. In the FT-IR measurements, the concentrations of $\mathrm{CF}_{4}, \mathrm{CHF}_{3}, \mathrm{CHClF}_{2}, \mathrm{HCl}$, and $\mathrm{HF}$ gases were analyzed five times and $C_{\text {in }}, C_{\text {out }}, C_{\mathrm{HCl}}$, and $C_{\mathrm{HF}}$ represent the average values obtained. The decomposition ratio of $\mathrm{CF}_{4}, \mathrm{CHF}_{3}$, and $\mathrm{CHClF}_{2}$ and the yield of $\mathrm{HCl}$ and/or $\mathrm{HF}$ from halide decomposition are defined by the following three equations:

Decomposition ratio of halides $=\frac{C_{\text {in }}-C_{\text {out }}}{C_{\text {in }}}$

Yield of $\mathrm{HCl}=\frac{C_{\mathrm{HCl}}}{\left(C_{\text {in }}-C_{\text {out }}\right) \times m}$ 
Yield of $\mathrm{HF}=\frac{C_{\mathrm{HF}}}{\left(C_{\text {in }}-C_{\text {out }}\right) \times n}$

where $C_{\text {in }}$ and $C_{\text {out }}[\mathrm{ppm}]$ are the inlet concentration and the outlet concentration of the halide, $\mathrm{C}_{\mathrm{HCl}}$ and $\mathrm{C}_{\mathrm{HF}}$ are the concentrations of $\mathrm{HCl}$ and $\mathrm{HF}$ in the decomposition products. The letters $m$ and $n$ are the respective numbers of $\mathrm{Cl}$ and $\mathrm{F}$ atoms in the halide compounds.

Regarding the decomposition of $\mathrm{CHClF}_{2}, \mathrm{CO}_{2}$ fraction was defined as followed:

$\mathrm{CO}_{2}$ fraction $=\frac{C_{\mathrm{CO}_{2}}}{\left(C_{\text {in }}-C_{\text {out }}\right)}$

where $\mathrm{C}_{\mathrm{CO} 2}$ is the concentration of $\mathrm{CO}_{2}$ in the decomposition products.

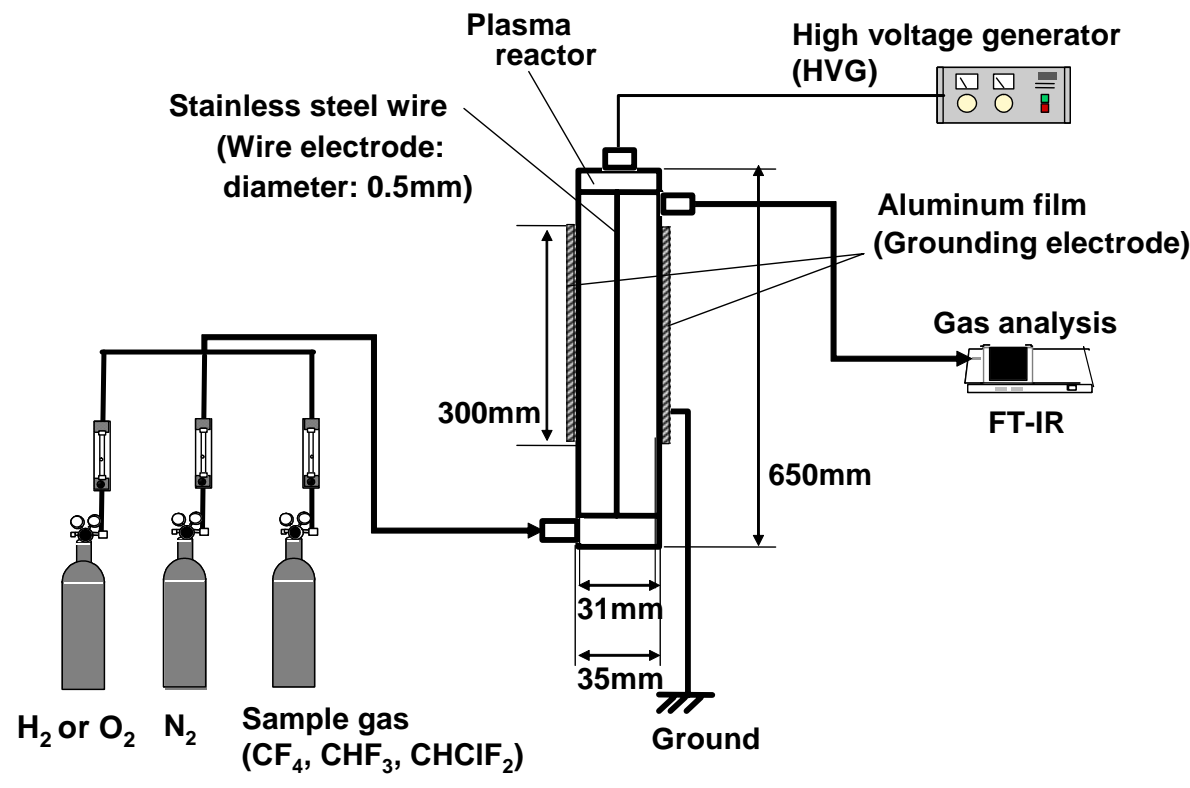

Figure 1. Experimental apparatus

\section{RESULTS AND DISCUSSION}

\subsection{Decomposition of halides by non-thermal plasma under $\mathrm{N}_{2}$ atmosphere}

Figure 2 shows the decomposition of three different halide gases $\left(\mathrm{CF}_{4}, \mathrm{CHF}_{3}\right.$ and $\left.\mathrm{CHClF}_{2}\right)$ as a function of power input to the plasma reactor.

As can be seen, the decomposition of halide gases started at input powers above $0.04 \mathrm{~kW}$, and thus it was considered that an input power above $0.04 \mathrm{~kW}$ was necessary for the formation of non-thermal plasma with corona discharge in this type of reactor. Further, regarding the type of halide gas used, the decomposition of chlorine containing halide gas of $\mathrm{CHClF}_{2}$ was found to be easier than that of $\mathrm{CF}_{4}$ and $\mathrm{CHF}_{3}$. In addition, the decomposition of $\mathrm{CF}_{4}$ was found to be the most difficult to achieve.

In $\mathrm{N}_{2}$ gas, the plasma decomposition of halide compounds was most likely initialized by dissociative electron attachment reactions generating chemically active $\mathrm{Cl}$ and/or $\mathrm{F}$ atoms and followed by a chain of radical reactions to form the final products.

The products of $\mathrm{HCl}$ and $\mathrm{HF}$, once formed by halide decomposition, did not participate in further reactions because of the relatively strong $\mathrm{H}-\mathrm{Cl}$ and $\mathrm{H}-\mathrm{F}$ bonds. However, the $\mathrm{Cl}$ and $\mathrm{F}$ atoms produced might have reacted together to form molecular $\mathrm{Cl}_{2}$ and $\mathrm{F}_{2}$. Given this, the major end products of plasma processing in $\mathrm{N}_{2}$ gas were considered to be $\mathrm{HCl}, \mathrm{HF}$ and $\mathrm{F}_{2}$ for $\mathrm{CHClF}_{2} ; \mathrm{HF}$ and $\mathrm{F}_{2}$ for $\mathrm{CHF}_{3}$; and $\mathrm{F}_{2}$ for $\mathrm{CF}_{4}$. Such a conclusion was further supported by the fact that no significant amount of organic compounds was detected by infrared spectroscopy of the decomposition products. Regarding the carbon atoms of halide gases, it was considered that carbon might have been converted to some kind of tar found coated on the electrodes in the reactor. Further, in the plasma decomposition process of $\mathrm{CF}_{4}$, no $\mathrm{F}$ scavenging reactions like that of $\mathrm{CHF}_{3}$ and $\mathrm{CHClF}_{2}$ decomposition occurred to form a 
chemically stable hydrogen halide product. Hence, the $\mathrm{F}$ atoms derived from a $\mathrm{CF}_{4}$ molecule were supposed to react with a $\mathrm{CF}_{3}$ radical to form $\mathrm{CF}_{4}$ again, and as a consequence, low decomposition ratios were achieved. Finally, to summarize this part, the higher decomposition ratios obtained for $\mathrm{CHClF}_{2}$ were attributed to the low bond energy of $\mathrm{C}-\mathrm{Cl}$ bond $\left(342 \mathrm{~kJ} \mathrm{~mol}^{-1}\right)$ in contrast to those of $\mathrm{C}-\mathrm{H}$ and $\mathrm{C}-\mathrm{F}$ bonds.

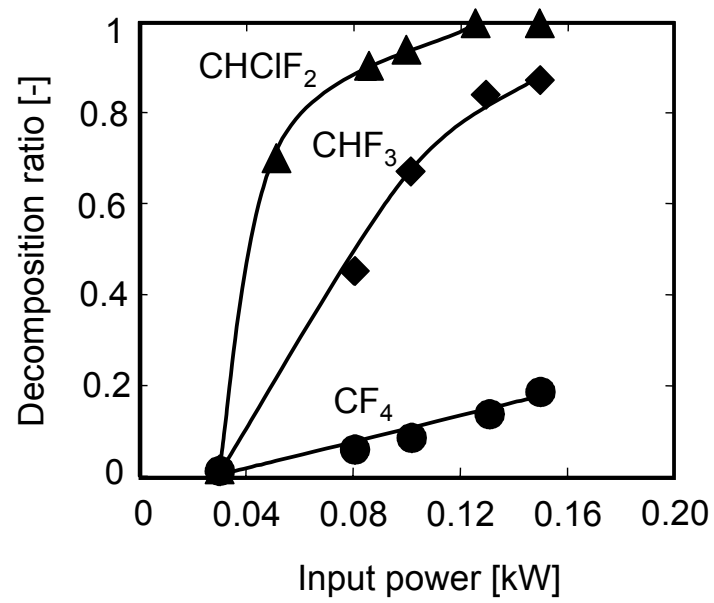

Figure 2. Decomposition of $\mathrm{CF}_{4}, \mathrm{CHF}_{3}$, and $\mathrm{CHClF}_{2}$ under $\mathrm{N}_{2}$ atmosphere

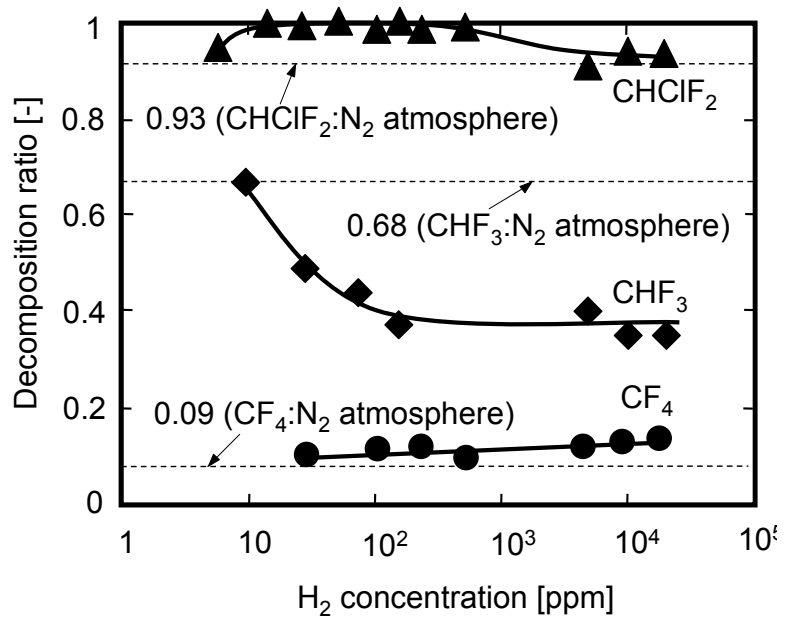

Figure 3. Effect of $\mathrm{H}_{2}$ concentration on the decomposition of halide gases $\left(\mathrm{CF}_{4}, \mathrm{CHF}_{3}\right.$, $\mathrm{CHClF}_{2}$ ) in $0.10 \mathrm{~kW}$

\subsection{Effect of $\mathbf{H}_{2}$ concentration on the decomposition of halides by non-thermal plasma}

In the plasma decomposition of halide gases, the halogen atoms released by halide decomposition could be relatively easily converted to stable hydrogen halides, subsequently removable from the gas stream using an alkali absorbent. To achieve this goal, $\mathrm{H}_{2}$ was introduced to the reactor and the effect of $\mathrm{H}_{2}$ concentration on the decomposition of halides by non-thermal plasma was studied. Figure 3 shows the effect of $\mathrm{H}_{2}$ concentration on the decomposition ratios of $\mathrm{CF}_{4}, \mathrm{CHF}_{3}$ and $\mathrm{CHClF}_{2}$ at the fixed input power of $0.10 \mathrm{~kW}$. In general, it can be seen that the decomposition ratio increased in order of $\mathrm{CHClF}_{2}>\mathrm{CHF}_{3}>\mathrm{CF}_{4}$.

At first, regarding the decomposition of $\mathrm{CF}_{4}$, higher decomposition ratios were obtained under $\mathrm{H}_{2}-\mathrm{N}_{2}$ atmosphere compared to decomposition ratio 0.09 obtained under $\mathrm{N}_{2}$ atmosphere and the decomposition ratios slightly increased with an increase in $\mathrm{H}_{2}$ concentration. It was considered that, under $\mathrm{H}_{2}-\mathrm{N}_{2}$ atmosphere, $\mathrm{HF}$ was formed by recombination of $\mathrm{F}$ and $\mathrm{H}$ atoms released by plasma decomposition of $\mathrm{CF}_{4}$ and $\mathrm{H}_{2}$, respectively. Then, as a consequence of $\mathrm{HF}$ formation, the recombination of $\mathrm{CF}_{3}$ radical with $\mathrm{F}$ yielding the initial halide gas of $\mathrm{CF}_{4}$ was assumed to be effectively hindered, which brought about higher decomposition ratios of $\mathrm{CF}_{4}$ in the presence of $\mathrm{H}_{2}$.

Further, in the case of $\mathrm{CHF}_{3}$, the $\mathrm{CHF}_{3}$ decomposition ratio was found to significantly drop when $\mathrm{H}_{2}$ gas was added to $\mathrm{N}_{2}$ atmosphere, and the decomposition ratio of only about 0.4 was obtained at $\mathrm{H}_{2}$ concentration higher than $75 \mathrm{ppm}$. Decomposition of $\mathrm{CHF}_{3}$ was expected to be initiated by a release of $\mathrm{H}$ atom of the $\mathrm{C}-\mathrm{H}$ bond $\left(410 \mathrm{~kJ} \mathrm{~mol}^{-1}\right)$ rather than by a dissociation of $\mathrm{F}$ atom from the $\mathrm{C}-\mathrm{F}$ bond $\left(472 \mathrm{~kJ} \mathrm{~mol}^{-1}\right)$. Thus, $\mathrm{CHF}_{3}$ decomposition mechanism in the plasma reaction field was supposed to proceed via formation of $\mathrm{H}_{\text {and }} \mathrm{CF}_{3}$ radicals. However, when the $\mathrm{H}_{2}$ gas concentration in the plasma reaction field was increased, the free $\mathrm{H}$ atom was recombined with $\mathrm{CF}_{3}$ radical to form back $\mathrm{CHF}_{3}$, and consequently the decomposition of $\mathrm{CHF}_{3}$ was significantly reduced.

Finally, the decomposition ratio of $\mathrm{CHClF}_{2}$ increased with an increase in $\mathrm{H}_{2}$ concentration and the decomposition ratio as high as 1.0 was achieved between $25 \mathrm{ppm}$ and $510 \mathrm{ppm} \mathrm{H}_{2}$. It was considered that the halogen atoms $(\mathrm{Cl}$ and $\mathrm{F})$ were converted to $\mathrm{HCl}$ and $\mathrm{HF}$ in a hydrogenenriched atmosphere, which brought about the promotion of decomposition. Although the decomposition of $\mathrm{CHClF}_{2}$ can be hindered in the presence of free $\mathrm{H}$ atom as in the case of 
$\mathrm{CHF}_{3}$, it was assumed that the decomposition proceeded in $\mathrm{H}_{2}$ atmosphere owing to the low bond energy of $\mathrm{C}-\mathrm{Cl}$ bond.

Figure 4 shows a comparison of $\mathrm{HCl}$ and $\mathrm{HF}$ yields from the decomposition of $\mathrm{CHClF}_{2}$ with and without $2 \% \mathrm{H}_{2}$ in sample gas as a function of input power. It was found that the yields of $\mathrm{HCl}$ and $\mathrm{HF}$ increased with $2 \% \mathrm{H}_{2}$ addition to gas stream, and $\mathrm{HCl}$ yield of 1.0 was obtained at the input power above $0.12 \mathrm{~kW}$. Such a result indicated that the hydrogen in gas stream participated in halide decomposition reactions to form the final products of $\mathrm{HCl}$ and $\mathrm{HF}$.
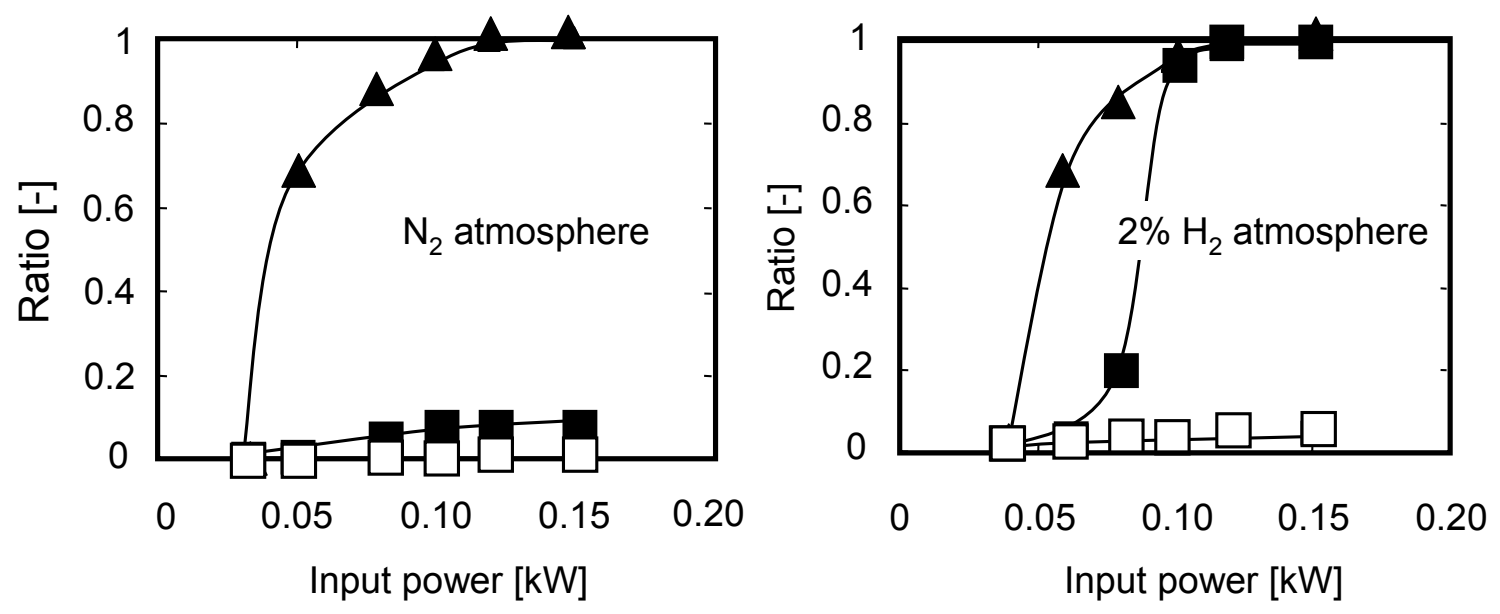

Figure 4. The yields of $\mathrm{HCl}$ and $\mathrm{HF}$ as a function of pulsed voltage in the decomposition of $\mathrm{CHClF}_{2}$

$\Delta$ : Decomposition ratio of $\mathrm{CHClF}_{2}$, $\mathbf{m}$ : Conversion of $\mathrm{Cl}$ to $\mathrm{HCl}$, $\square$ : Conversion of $\mathrm{F}$ to $\mathrm{HF}$

To summarize the results presented in Figures 3 and 4, it was considered that the presence of $\mathrm{H}_{2}$ can result in either promotion or prevention of halide gases decomposition. At first, the promotion of the decomposition occurred when the halogen atoms released from halide gases preferentially reacted with free $\mathrm{H}$ atom to form stable hydrogen halides. As a consequence, the back formation of an initial halide gas was effectively hindered. By contrast, the prevention of the decomposition of halide gases is likely to take place for halide gases containing an $\mathrm{H}$ atom in their molecule. In such a case, the presence of free $\mathrm{H}$ atom in the plasma reaction field could lead to a shift in the reaction equilibrium towards the initial halide gas, since the decomposition of halide gases starts with the removal of $\mathrm{H}$ atom from a halide gas.

\subsection{Non-thermal plasma decomposition of halide gases in $\mathrm{O}_{2}-\mathrm{N}_{2}$ atmosphere}

In order to achieve oxidation of carbon present in halide gases to $\mathrm{CO}_{2}$, the non-thermal plasma decomposition of halide gases was conducted at $0.12 \mathrm{~kW}$ under $\mathrm{O}_{2}-\mathrm{N}_{2}$ atmosphere, of which the $\mathrm{O}_{2}$ concentration was adjusted to $0-20,000 \mathrm{ppm}$. Figure 5 shows the decomposition ratios obtained under $\mathrm{O}_{2}-\mathrm{N}_{2}$ atmosphere for $\mathrm{CF}_{4}, \mathrm{CHF}_{3}$ and $\mathrm{CHClF}_{2}$. As seen in this figure, the decomposition ratio of $\mathrm{CHF}_{3}$ decreased with an increase of $\mathrm{O}_{2}$ concentration. The decomposition ratio of $\mathrm{CHClF}_{2}$ as high as 1.0 was achieved in the $\mathrm{O}_{2}$ concentration range of $25 \mathrm{ppm}$ to $2,500 \mathrm{ppm}$. However, the decomposition ratio of $\mathrm{CHClF}_{2}$ decreased when $\mathrm{O}_{2}$ concentration was increased above $2,500 \mathrm{ppm}$. Finally, the decomposition of $\mathrm{CF}_{4}$ did not take place in the whole $\mathrm{O}_{2}$ concentration range used.

It was considered that, in the presence of $\mathrm{O}_{2}$ in the gas stream, $\mathrm{O}$ radical was generated by a reaction of $\mathrm{O}_{2}$ molecule with an electron, and consequently $\mathrm{O}_{3}$ was formed by a reaction between $\mathrm{O}_{2}$ and $\mathrm{O}$ radical. Then, as a result of these reactions, a significant portion of input energy was consumed for excitation and dissociation of $\mathrm{O}_{2}$ molecules, which presumably led to a decrease in decomposition ratio of halide gases. 


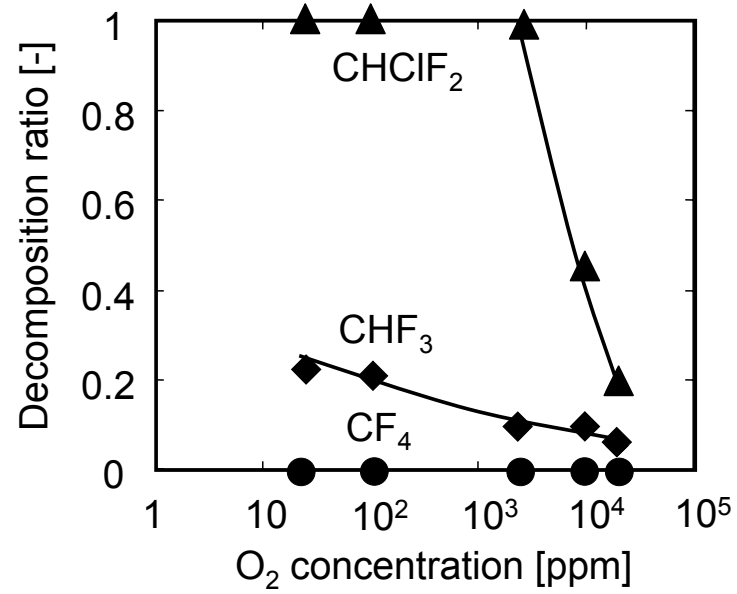

Figure 5. Effect of $\mathrm{O}_{2}$ atmosphere on halide decomposition by non-thermal plasma

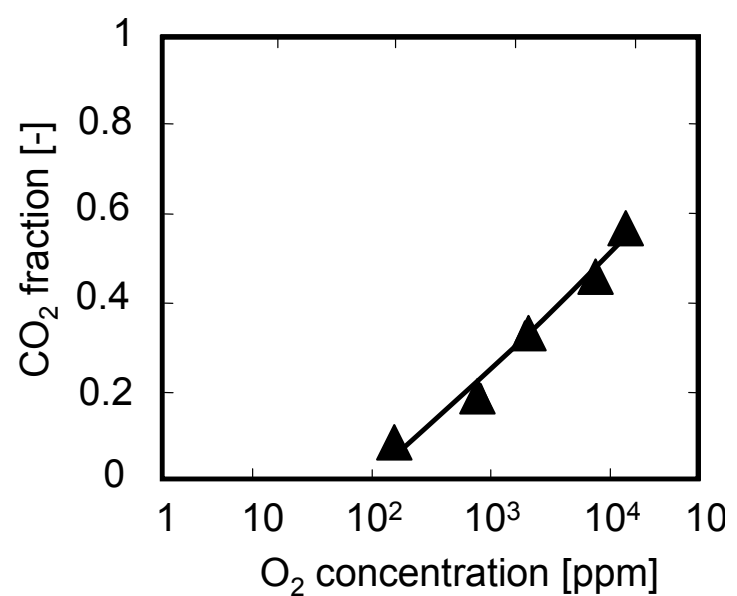

Figure 6. Effect of $\mathrm{O}_{2}$ atmosphere on $\mathrm{CO}_{2}$ formation in the decomposition halide gases

Furthermore, the reaction products of $\mathrm{CHClF}_{2}$ decomposition under $\mathrm{O}_{2}-\mathrm{N}_{2}$ atmosphere were analyzed and the reaction products of $\mathrm{COF}_{2}, \mathrm{COCl}_{2}$ and desirable product of $\mathrm{CO}_{2}$ were determined. Figure 6 shows the effect of $\mathrm{O}_{2}$ concentration on the formation of $\mathrm{CO}_{2}$ in nonthermal plasma decomposition of $100 \mathrm{ppm} \mathrm{CHClF}_{2}$ at $0.12 \mathrm{~kW}$. It can be seen that $\mathrm{CO}_{2}$ fraction increased with an increase in $\mathrm{O}_{2}$ concentration, which confirmed a positive effect of $\mathrm{O}_{2}$ on the formation of $\mathrm{CO}_{2}$.

\section{CONCLUSIONS}

The effects of $\mathrm{H}_{2}$ and $\mathrm{O}_{2}$ concentrations on the non-thermal plasma decomposition of $\mathrm{CF}_{4}$, $\mathrm{CHF}_{3}$ and $\mathrm{CHClF}_{2}$ were investigated in this study. As a result, it was found that the decompositions of $\mathrm{CF}_{4}$ and $\mathrm{CHClF}_{2}$ were promoted by the presence of $\mathrm{H}_{2}$. On the other hand, the decomposition ratio of $\mathrm{CHF}_{3}$ decreased with an increase in $\mathrm{H}_{2}$ concentration. As for the non-thermal plasma decomposition of halides under $\mathrm{O}_{2}-\mathrm{N}_{2}$ atmosphere, decomposition ratios of all halides employed were observed to decrease in the presence of $\mathrm{O}_{2}$. However, the formation of desirable end-product of $\mathrm{CO}_{2}$ significantly increased with an increase in $\mathrm{O}_{2}$ concentration. Finally, it was showed that the decomposition of halide gases and the formation of reaction products can be controlled by changing the reaction conditions.

\section{ACKNOWLEDGMENT}

This research was supported by Grant-in-Aid for Scientific Research (B)(2) (No. 15310051) from the Ministry of Education, Culture, Sports, Science and Technology of Japan.

\section{REFERENCES}

Kataoka, O. (2001) The present status of freon substitution (in Japanese), Environmental Technology, 30(2), 93-96.

Mizuno K. (2001) Technology for Countermeasure of Destruction of Ozone layer (in Japanese), Environmental Technology, 30(2), 87-88.

Oda T., Yamashita R., Takahashi T. and Masuda S., (1996) Atmospheric Pressure Discharge Plasma Decomposition for Gaseous Air Contaminants Trichlorotrifluoroethane and Trichloroethylene, IEEE Trans. Ind. Appl., 32(2), 227-232.

Sathiamoorthy G., Locke B.R., Finney W.C., Clark R.J. and Yamamoto T., (1999) Halon Destruction in a Gas Phase Pulsed Streamer Corona Reactor, J. Adv. Oxid. Techol., 4(4), 375-379.

Huang L., Nakajo K., Ozawa S. and Matsuda H., (2001) Decomposition of Dichloromethane in a Wire-in-tube Pulsed Corona Reactor, Environ. Sci. Technol., 35(6), 1276-1281.

Hari T. Nakajo K., Huang L., Kojima Y., Ozawa S. and Matsuda H., (2002) Influence of the Coexistence Gas and In-Situ Solid Absorbent on the Decomposition of Covalent Chlorides and Fluorides by Non-thermal Plasma, Kagaku Kogaku Ronbunshu, 28, 522-527. 